\title{
Optimization of multibiosensor usage for inhibitory analysis of toxins
}

\author{
O.O. Soldatkin, O.S. Pavluchenko', O.L.Kukla', V.M. Arkhypova, S.V. Dzyadevych,
} A.P. Soldatkin, A.V. El'skaya

Institute of molecular biology and genetics NAS of Ukraine

150, Zabolotnogo Str, Kyiv Ukraine, 03680

${ }^{1}$ V.Lashkaryov Institute of Semiconductor Physics

41, prospect Nauki, Kyiv, Ukraine, 03028

alex_sold@yahoo.com

\begin{abstract}
The operation of highly sensitive and selective multibiosensor based on several immobilized enzymes as bioselective elements and a matrix of $\mathrm{pH}$-sensitive field effect transistors as transducers of the biochemical signal into electric one has been investigated. To develop bioselective elements of multibiosensor, the enzymes highly sensitive to toxins, such as acetylcholinesterase, butyrylcholinesterase, urease, glucose oxidase, and a three-enzyme system (invertase, mutarotase, glucose oxidase), were used. Optimal substrates concentrations for inhibitory analysis were determined to be: $10 \mathrm{mM}$ acetylcholine, $5 \mathrm{mM}$ butyrylcholine, $5 \mathrm{mM}$ urea, $5 \mathrm{mM}$ sucrose, and $2 \mathrm{mM}$ glucose. It was shown that there was practically no cross-influence of the substrates on the used enzyme systems. Time of incubation of the multibiosensor in solutions with toxic compounds was 20 min. The inhibitory influence of separate toxins and their mixtures on bioselective elements of multibiosensors was studied.
\end{abstract}

Keywords: multibiosensor, immobilized enzymes, $p H$-sensitive field-effect transistors, inhibitory analysis, toxins.

Introduction. Quick monitoring of numerous toxic compounds in environment, consumer goods and foods became extremely urgent during last decades. Therefore, the development of different biosensor devices for these purposes is the mainstream of modern analytical bio- and chemotechnology. At present, a number of monobiosensors have been elaborated worldwide [1-8] for toxin determination, some of them - for direct [1-4], and others - for inhibitory analysis [5-9]. Enzymes [1-3, 6-9] and microorganisms [4, 5] as bioselective elements, and different physical

(C) O.O. SOLDATKIN, O.S. PAVLUCHENKO, O.L.KUKLA, V.M. ARKHYPOVA, S.V. DZYADEVYCH, A.P. SOLDATKIN, A.V. EL'SKAYA, 2008 transducers and measuring circuits were used in these biosensors. However, the selectivity of single monobiosensors is regularly insufficient for qualitative and quantitative determinations of toxins in the tested sample. These biosensors can be used only to determine a single toxic compound or one class of toxic compounds (total toxicity). That is why most studies on monosensors for toxin determination led to conclusion that occurring challenge can be overcome by development of multibiosensors. Currently, a conception of multibiosensors for ecological monitoring is suggested, a possibility of their development is shown in principle [10], and several laboratory prototypes of multibiosensor devices based 
on transducers of different types and various bioselective elements are now on trial [11-13]. In our opinion, the most prospective is a multibiosensor based on inhibitory analysis, where immobilized enzymes (or their mixture) and a matrix of $\mathrm{pH}$-sensitive field-effect transistors (pH-FET) are used.

For bioselective elements of a multibiosensor, the enzymes acetylcholinesterase, butyrylcholinesterase, urease, glucose oxidase, and a three-enzyme system invertase-mutarotase-glucose oxidase were suggested as the most promising with regards to inhibitory analysis. These enzymes will enable selective determination of such toxins, as organophosphorous and chlorine organic pesticides, carbamate herbicides, and heavy metal ions. The first steps in the development of such multibiosensor were described in our previous publication [14]: the immobilization method optimal for all used enzymes was experimentally tested; the conditions of concurrent work of bioselective elements were optimized; a possibility of direct analysis of some substrates was examined. This work is a logical continuation of our previous investigation and is aimed to adaptation and application of the multibiosensor for inhibitory analysis.

Materials and methods. Materials. The following frozen-dried preparations of enzymes: soybean urease (activity index of $31 \mathrm{U} / \mathrm{mg}$ ) (Fluka, Switzerland); acetylcholinesterase (AChE) (activity index of 426 $\mathrm{U} / \mathrm{mg}$ ) of electric eel (Sigma-Aldrich Chemie, USA); butyrylcholinesterase (BuChE) (activity index 13 $\mathrm{U} / \mathrm{mg}$ ) of horse blood serum (Sigma-Aldrich Chemie), glucose oxidase (GOD) of Penicilium vitale (activity index $130 \mathrm{U} / \mathrm{mg}$ ) (Diagnosticum, Ukraine); baker's yeast invertase (activity index of $355 \mathrm{U} / \mathrm{mg}$ ) (Sigma-Aldrich Chemie), pig kidney mutarotase (activity index of $100 \mathrm{U} / \mathrm{mg}$ ) (Biozyme Laboratories Ltd, UK). Bovine serum albumin (BSA) (fraction V) and $50 \%$ aqueous solution of glutaraldehyde (GA) were purchased from Sigma-Aldrich Chemie. The following substrates were used: urea, butyrylcholine chloride $\mathrm{BuChCl}$, acetylcholine chloride $\mathrm{AChCl}$, glucose, and sucrose.

Aqueous solutions of heavy metals nitrates (domestic production), trichlorophon [(dimethyl-2, 2, 2- trichlor - 1 - hydroxyethyl) - phosphonat] (phosphorous organic pesticide, production of Riedel-de-Haen, Switzerland), carbofuran (2, 3 dihydro - 2,2 - dimethylbenzofuran - 7 - yl $\mathrm{N}$-methylcarbamate) (carbamate pesticide, production of Riedel-de-Haen, Switzerland) were used as enzyme inhibitors. Phosphate solution $\left(\mathrm{KH}_{2} \mathrm{PO}_{4}-\mathrm{NaOH}\right)$ was chosen as a working buffer with $2 \mathrm{mM}$ concentration and $\mathrm{pH}$ 6,5. Other inorganic compounds used were of analytical grade quality.

Preparation of bioselective membranes. To produce working bioselective elements based on AChE, BuChE, urease, and GOD, the solutions of the following composition were prepared: $10 \%$ enzyme + $10 \%$ BSA, and for three-enzyme system $-6 \%$ invertase $+6 \%$ mutarotase $+5 \%$ GOD $+3 \%$ BSA (hereinafter three-enzyme solution). The enzymes were dissolved in $40 \mathrm{mM}$ phosphate buffer, pH 6.5, with $20 \%$ glycerol. The reference membrane mixture was made in the same way but only $20 \%$ BSA was used. Prior to deposition on the transducer surface, both mixtures, for reference and working membranes, were mixed with $2 \%$ aqueous solution of GA (1:1). Solutions obtained were deposited immediately on the transducers using Eppendorf automatic pipette (total volume 0.1-2.5 $\mu \mathrm{l}$ ) till complete covering of the working surfaces was achieved. The volume applied on each membrane was about $0.1 \mu \mathrm{l}$; all membranes contained on their surfaces the same total amount of proteins. Next, the membranes were dried for $12 \mathrm{~h}$ at room temperature, and prior to use, washed from excess of unbound GA with the buffer solution.

Construction of sensor elements. A common topological requirement of $\mathrm{pH}$-sensitive field effect transistors ( $\mathrm{pH}-\mathrm{FET}$ ) for biochemical laboratories is a free and easy access to the active sensitive (gate) region of sensor elements for bioselective membrane deposition. For this purpose, the gate zone and metal contacts are placed on separate parts of the crystal that makes active parts of transistors easily accessible and electric contacts reliably isolated from the solution. The schematic picture of a typical multichannel sensor line (Fig. 1) shows mentioned above topological peculiarities of the pH-FET elements that form the sensor array. The silicon lines of integral $\mathrm{pH}-\mathrm{FET}$ sensors were manufactured in Science-and-Production Association "Quazar” (Kiev, Ukraine). 


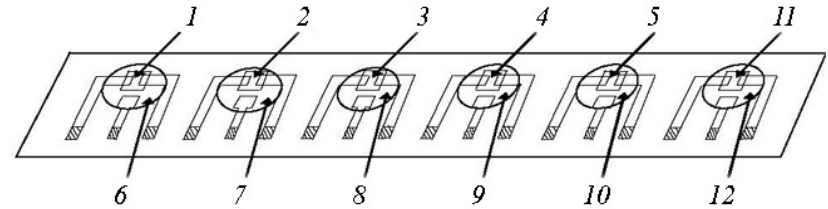

Fig. 1. Sensor line of $\mathrm{pH}$-sensitive field-effect transistors $(1-5,11)$ with layers of enzymes (6-10) immobilized on gate surfaces, (11)a reference transistor transducer with neutral BSA layer (12).

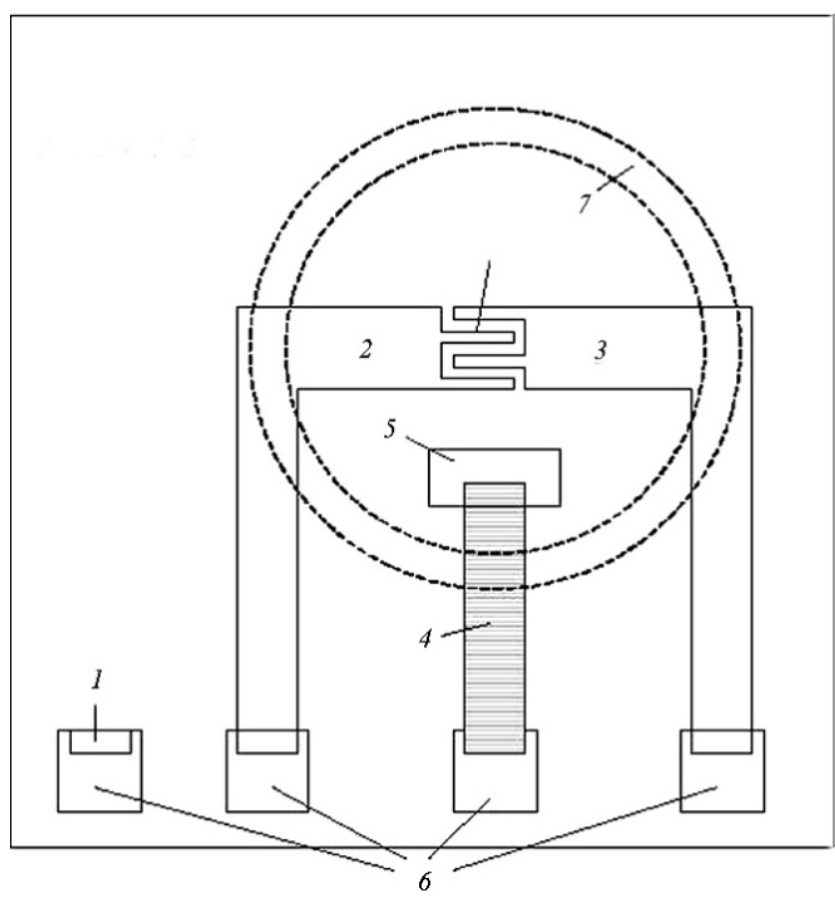

Fig. 2. Topology of separate pH-FET sensor element: 1 - contact to substrate n-zone, $2-p^{+}$-diffusion contact bars from transistor source and drain parts, 3 - gate zone, 4 - contact to integrated reference electrode, 5 - silver chloride layer, 6 - aluminum contact planes to transistor outputs, 7 - placement of ring seal for transistor active zone.

The topology of typical pH-FET transducer is presented in Fig. 2. The gate with $\mathrm{pH}$-sensitive layer of silicon nitride is patterned as a raster "snake" to increase the channel length-to-width ratio. The value of this ratio is close to 200 ensuring high transistor amplification. The threshold transistor voltage is typically about $2.5 \mathrm{~V}$.

One of the FET key problems is reliable seal of contacts, substrate and cutting lines of transistor chips from electrolyte, since this factor defines service life of

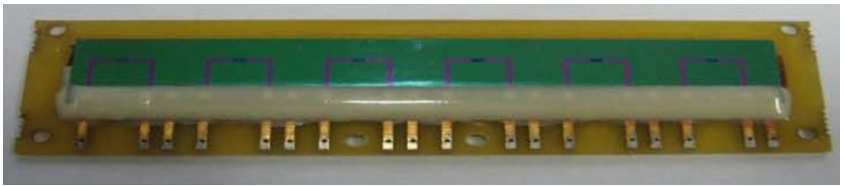

Fig. 3. Photo of 6-channel sensor line on the basis of silicon pH-FETs.

the device in general. The source and drain lines, $7 \mathrm{~mm}$ distant from each other, are brought out by long diffusion bars to the plate edge where the output electrodes are soldered and then encapsulated with the compound. Besides, the adopted overall dimensions assumed that the gate zone was sufficiently remote from the cutting line (the plate edge) and, thus, the liquid flow had no effect on the function of sensor element. A distinguishing feature of described structure is complete covering of the plate surface with a silicon nitride dielectric layer. The latter, being a $\mathrm{pH}$-sensitive gate of FET-elements, serves also as a reliable chemical-resistant insulating layer of the whole crystal.

Photography of the 6-channel sensor line, assembled on a special universal plate with reliable insulation of all electric contacts, is shown on Fig. 3.

For the measurement of $\mathrm{pH}-\mathrm{FET}$ sensor response, the circuit was used to sustain constant source current of each transistor, so that the output signal automatically follows any voltage change near the transistor gate. Conditions of measurement: channel current $I_{c}=20-30 \mu \mathrm{A}$, drain-source voltage $U_{c s} \approx 1 \mathrm{~V}$, substrate voltage $U_{n}=0$, transistor output signal within the range of $2.7-3.0 \mathrm{~V}$. This multichannel device allowed its usage in the differential mode of measurement, i.e. one of the transistors serves as a referent electrode while the others, covered with a sensitive enzyme layers, are measuring electrodes. The differential mode permitted considerable reduction of temperature and solution ion strength fluctuation influences, light effect and electromagnetic interference on the results of measurement. Besides, the device noise decreased remarkably.

Measurement procedure. Measurement was performed at room temperature in a flow cell filled with $2 \mathrm{mM}$ phosphate buffer, $\mathrm{pH}$ 6.5. The substrate concentrations were varied by addition of diluted 
standard initial substrates solutions. The enzymes were inhibited by 20 -min exposition of the multibiosensor chip in solutions with different toxins and their mixtures in the range of concentrations from 1 to 1000 $\mu \mathrm{M}$. Each experiment was repeated at least three times. Nonspecific changes in the output signal associated with fluctuations of temperature, medium $\mathrm{pH}$ and electric noise were eliminated due to usage of the differential measurement mode.

Results and discussion. Function of the multibiosensor for inhibitory analysis of toxins is based on the effect of inhibition of following single enzymatic reactions or cascades of enzymatic reactions:

$$
\begin{aligned}
& \text { Urease } \\
& \text { Urea }+2 \mathrm{H}_{2} \mathrm{O}+\mathrm{H}^{+} \rightarrow 2 \mathrm{NH}_{4}^{+}+\mathrm{HCO}_{3}^{-} \\
& \mathrm{BuChE} \\
& \text { Butyrylcholine }+\mathrm{H}_{2} \mathrm{O} \rightarrow \text { Choline }+\mathrm{CH}_{3}\left(\mathrm{CH}_{2}\right)_{2} \mathrm{COO}^{-}+\mathrm{H}^{+} \\
& \text {AChE } \\
& \text { Acetylcholine }+\mathrm{H}_{2} \mathrm{O} \rightarrow \text { Choline }+\mathrm{CH}_{3} \mathrm{COO}^{-}+\mathrm{H}^{+} \\
& \text {GOD } \\
& \beta \text {-D-glucose }+\mathrm{O}_{2}+\mathrm{H}_{2} \mathrm{O} \rightarrow \text { D-gluconolacton }+\mathrm{H}_{2} \mathrm{O}_{2} \\
& \Downarrow \\
& \text { D-gluconic acid }+\mathrm{H}_{2} \mathrm{O} \leftrightarrows \text { acid residue }+\mathrm{H}^{+} \\
& \text {Invertase } \\
& \text { Sucrose }+\mathrm{H}_{2} \mathrm{O} \rightarrow \beta \text {-D-fructose }+\alpha \text {-D-glucose } \\
& \text { Mutarotase } \\
& \alpha \text {-D-glucose } \rightarrow \beta \text {-D-glucose } \\
& \text { GOD } \\
& \beta \text {-D-glucose }+\mathrm{O}_{2} \rightarrow \text { D-gluconolacton }+\mathrm{H}_{2} \mathrm{O}_{2} \text { (5.3) } \\
& \Downarrow \\
& \text { D-gluconic acid }+\mathrm{H}_{2} \mathrm{O} \leftrightarrows \text { acid residue }+\mathrm{H}^{+}
\end{aligned}
$$

The enzymatic reactions (1-3) and reaction cascades $(4,5)$ result in proton concentration changes (and corresponding local $\mathrm{pH}$ alteration of solution on the membrane). This allows usage of the matrix of $\mathrm{pH}$-sensitive field-effect transistors as transducers [15].

The typical experimental signals of multibiosensor in inhibitory analysis are demonstrated by the example of $\mathrm{Hg}^{2+}$ ions determination (Fig. 4). The initial signals $\left(\mathrm{X}_{1}, \mathrm{X}_{2}, \mathrm{X}_{3}, \mathrm{X}_{4}, \mathrm{X}_{5}\right)$ of the multibiosensor obtained after injection of the substrates mixture $(10 \mathrm{mM} \mathrm{ACh}, 5 \mathrm{mM}$ $\mathrm{BuCh}, 5 \mathrm{mM}$ urea, $5 \mathrm{mM}$ sucrose, and $2 \mathrm{mM}$ glucose), were taken as $100 \%$. The biosensor was next placed for 20 min into corresponding toxin solution (in our case
$25 \mu \mathrm{M} \mathrm{Hg}^{2+}$ ), washed from the excess of toxin residues, and then the signals $\left(\mathrm{Y}_{1}, \mathrm{Y}_{2}, \mathrm{Y}_{3}, \mathrm{Y}_{4}, \mathrm{Y}_{5}\right)$ after injection of the same substrates mixture were measured again. The residue activities of $Z n$ were calculated by the formula $Z n=Y n * 100 / X n$, where $X n, Y n$ - the multibiosensor responses before and after its incubation in $\mathrm{Hg}^{2+}$ solution, correspondingly.

To obtain the highest sensitivity of the developed multibiosensor to some toxins, optimal substrate concentrations for the inhibitory analysis should be determined. Theoretically, the optimal value should be within the region of enzyme saturation by its substrate, where each enzyme molecule is maximally involved in the substrate transformation into a final product leading to $\mathrm{pH}$ change and, thus, in generation of the maximal signal. The dependence of multibiosensor responses on concentration of corresponding substrates was studied experimentally (Fig. 5). As can be seen, at increasing substrate concentrations the classical dependence was revealed. Therefore, in further experiments the substrate concentrations corresponding to maximum multibiosensor responses were used, i.e. the maximal enzyme saturation by substrates. Thus, the substrate concentrations were as following: $10 \mathrm{mM} \mathrm{ACh}, 5 \mathrm{mM}$ $\mathrm{BuCh}, 5 \mathrm{mM}$ urea, $5 \mathrm{mM}$ sucrose, and $2 \mathrm{mM}$ glucose.

Since all bioselective elements of a multibiosensor should concurrently function in the same medium under identical conditions, the substrate cross impact is to be studied for each separate bioselective element. The responses of a 5-element matrix to each separate substrate and to the substrates mixture are presented in Fig. 6. As can be seen, only urease and GOD (and, correspondingly, sensor elements based on these enzymes) were observed to be highly selective to their substrates urea and glucose, respectively. The AChEand BuChE-based biomembranes were characterized by some cross-sensitivity to the substrates acetylcholine and butyrylcholine, and no sensitivity was detected to the substrates of other enzymes. The bioselective element based on three enzymes, invertase, mutarotase and GOD, for sucrose determination was insensitive to all cross-substances except glucose. The influence of the latter is considerable and explicable due to the presence of GOD in its composition. All bioselective elements of the multibiosensor demonsrtated the same responses 


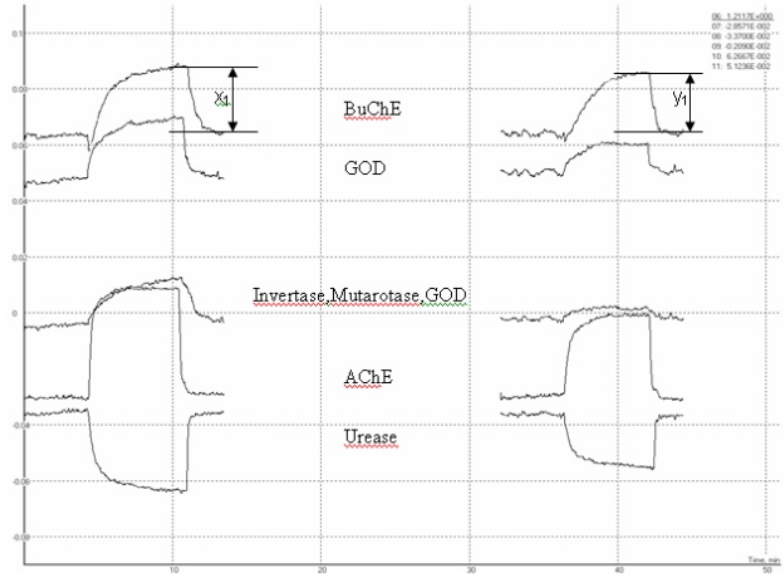

Fig. 4. Scheme of toxin determination by multibiosensor.

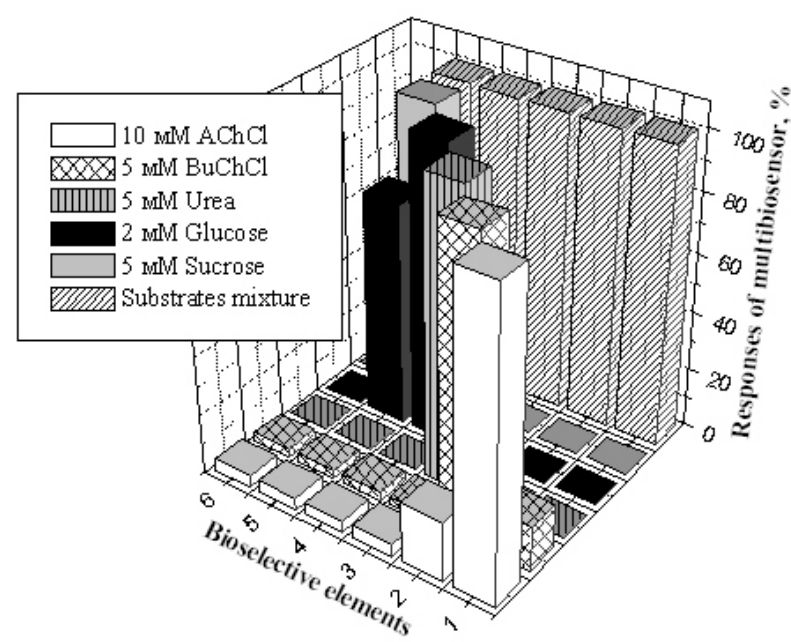

Fig. 6. Effect of separate substrates and their mixture on responses of bioselective elements of multibiosensor based on: 1 - AChE, 2 BuChE, 3 - urease, 4 - GOD, 5 - three-enzyme system, 6 - BSA.

either after injection of the mixture with all substrates or after separate addition of each substrate. One more proof of satisfactory work of the multibiosensor was a negligible effect (within the error limits) of all substrates and their mixture on the sensor element with the reference membrane containing BSA.

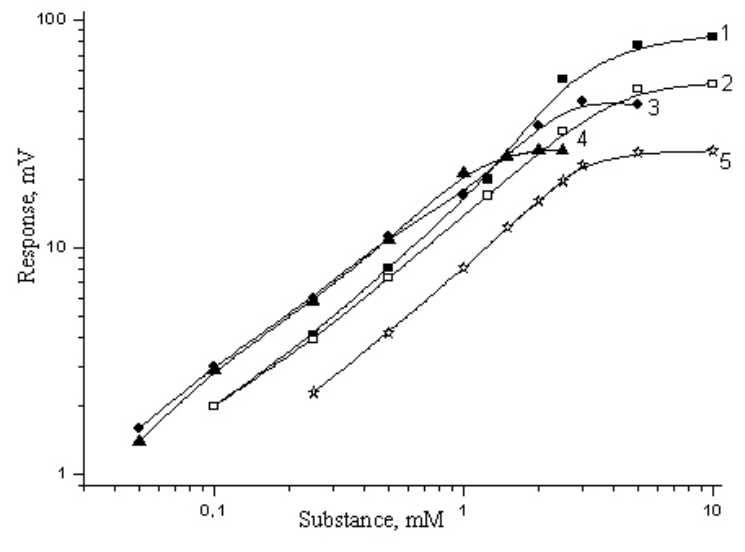

Fig.5. Dependence of responses of multibiosensor with enzymes (1 - AChE, 2 - urease, 3 - BuChE, 4 - GOD, 5 - three-enzyme system) immobilized on sensitive surfaces of transducers line on concentrations of corresponding substrates

All results demonstrating the cross impact of specific substrates on responses of different sensor elements of the multubiosensor are very important in case of its application in inhibitory analysis and will be taken into account for toxin determination in real samples of environment.

Time of multibiosensor incubation in tested solutions is also important factor since the measurement of very low toxin concentrations requires prolonged inhibition time. Therefore, it is necessary to choose compromise measurement conditions, which ensure determination of toxins at rather low concentrations in relatively short inhibition period that will result in the most effective mode of analysis. Thus, the next step in our study was the determination of optimal multibiosensor incubation time, common for all enzymatic systems used. Dependence of the inhibition level of immobilized enzymes on time of their incubation in the inhibitor solutions is presented on Fig. 7. The curves for bioselective elements based on enzymes urease, GOD and three-enzyme system invertase-mutarotase-glucose oxidase (Fig. 7a) demonstrate higher inhibition by heavy metals compared to pesticides, that is why $25 \mu \mathrm{M} \mathrm{Hg}^{2+}$ was used as a test inhibitor solution. But, for enzymes $\mathrm{AChE}$ and $\mathrm{BuChE}$ which are more inhibited by pesticides (Fig. 7b), $50 \mu \mathrm{M}$ trichlorphone was used as a test inhibitor solution. As can be seen from Fig. 7, the 
Inhibitory effect of toxins and their mixtures on enzymatic systems of the multibiosensor (complete inhibition is taken as 100\%).

\begin{tabular}{|c|c|c|c|c|c|}
\hline Inhibitor & Urease, $\%$ & $\mathrm{BuChE}, \%$ & $\mathrm{AChE}, \%$ & GOD, $\%$ & $\begin{array}{c}\text { Three-enzyme } \\
\text { system, } \%\end{array}$ \\
\hline 1 & 2 & 3 & 4 & 5 & 6 \\
\hline $1 \mu \mathrm{M}$ trichlorphone & 0 & 15 & 0 & 0 & 0 \\
\hline $10 \mu \mathrm{M}$ trichlorphone & 0 & 50 & 5 & 0 & 0 \\
\hline $1 \mu \mathrm{M}$ trichlorphone & 0 & 100 & 85 & 0 & 0 \\
\hline $10 \mathrm{mM}$ trichlorphone & 0 & 100 & 100 & 0 & -14 \\
\hline $1 \mu \mathrm{M}$ carbofuran & 0 & 25 & 5 & 0 & 0 \\
\hline $1 \mu \mathrm{M} \mathrm{Ag}+$ & 0 & 0 & 5 & 15 & 11 \\
\hline $10 \mu \mathrm{M} \mathrm{Ag}+$ & 0 & 3 & 25 & 60 & 65 \\
\hline $50 \mu \mathrm{M} \mathrm{Ag}+$ & 10 & 7 & 70 & 100 & 99 \\
\hline $0,2 \mu \mathrm{M} \mathrm{Hg} 2+$ & 0 & 0 & 0 & 0 & 5 \\
\hline $1 \mu \mathrm{M} \mathrm{Hg} 2+$ & 4 & 0 & 0 & 10 & 22 \\
\hline $10 \mu \mathrm{M} \mathrm{Hg} 2+$ & 25 & 3 & 10 & 50 & 70 \\
\hline $10 \mu \mathrm{M} \mathrm{Cd} 2+$ & 12 & 0 & 0 & 0 & 5 \\
\hline $50 \mu \mathrm{M} \mathrm{Cd} 2+$ & 65 & 0 & 15 & 10 & 30 \\
\hline $200 \mu \mathrm{M} \mathrm{Cd} 2+$ & 100 & 0 & 40 & 40 & 70 \\
\hline Mixture 1 & 12 & 85 & 80 & 90 & 100 \\
\hline Mixture 2 & 20 & 100 & 80 & 70 & 75 \\
\hline Mixture 3 & 0 & 100 & 60 & 40 & 50 \\
\hline Mixture 4 & 50 & 60 & 30 & 45 & 80 \\
\hline Mixture 5 & 40 & 80 & 40 & 30 & 55 \\
\hline Mixture 6 & 0 & 100 & 40 & 5 & 15 \\
\hline Mixture 7 & 40 & 60 & 7 & 15 & 30 \\
\hline Mixture 8 & 45 & 5 & 35 & 70 & 70 \\
\hline Mixture 9 & 30 & 100 & 100 & 100 & 100 \\
\hline
\end{tabular}


Table continuation

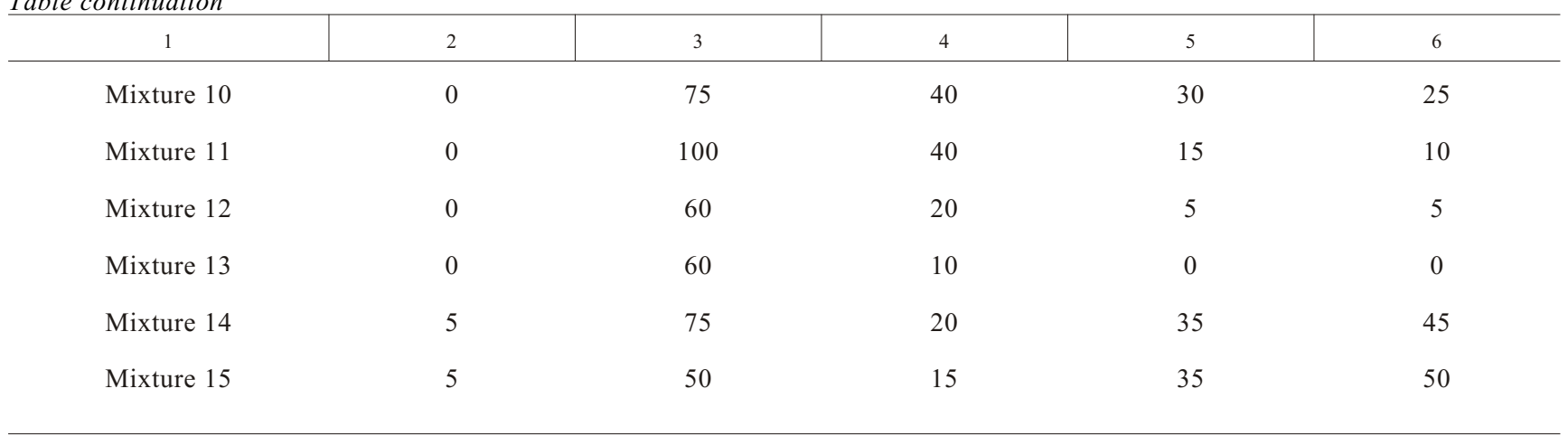

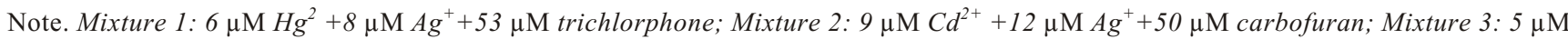
$\mathrm{Ag}^{+}+85 \mu \mathrm{M}$ carbofuran $+13 \mu \mathrm{M}$ trichlorphone; Mixture 4: $23 \mu \mathrm{MCd}^{2+}+5 \mu \mathrm{M} \mathrm{Hg}^{2}+10 \mu \mathrm{M}$ trichlorphone; Mixture 5: $25 \mu \mathrm{M} \mathrm{Cu} \mathrm{C}^{2+}+5 \mu \mathrm{M}$

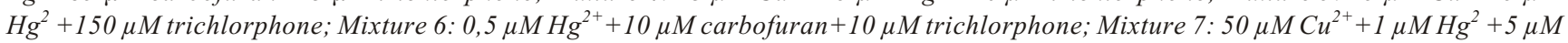

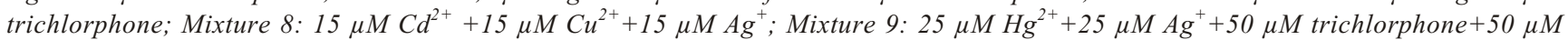

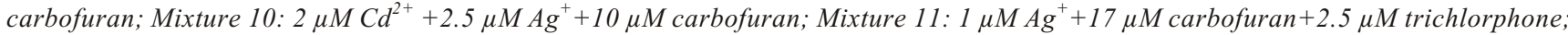
Mixture 12: $0.25 \mu \mathrm{M} \mathrm{Ag}^{+}+4 \mu \mathrm{M}$ carbofuran $+0.75 \mu \mathrm{M}$ trichlorphone; Mixture 13: $0.1 \mu \mathrm{M} \mathrm{Hg} \mathrm{H}^{2}+2 \mu \mathrm{M}$ carbofuran $+2 \mu \mathrm{M}$ trichlorphone;

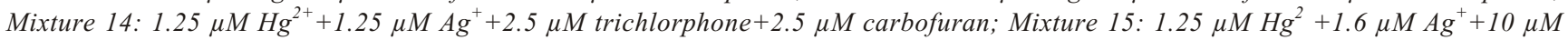
trichlorphone

inhibition of all enzymes is most intensive during first $20 \mathrm{~min}$, then inhibition of GOD and three-enzyme system becomes somewhat lower. That is why in further experiments the duration of multibiosensor incubation in toxin solutions was set to $20 \mathrm{~min}$. At this condition sufficiently high level of inhibition of all bioselective elements was achieved, interaction enzyme-toxin was intensive enough, and total time of the analysis was rather short.

The inhibitory effect of individual toxins and their mixtures on enzymatic systems used for the multibiosensor was next investigated. The results are presented in Table 1.

The experimental data presented in Table 1 will be further analyzed by methods of statistics in order to elaborate some approaches for quantitative or semiquantitative determination of toxin concentrations in real samples of environment.

Conclusion. The multibiosensor based on a matrix of $\mathrm{pH}$-sensitive field-effect transistors with immobilized enzymes acetyl- and butyryl- choline esterases, urease, glucose oxidase, and three-enzyme system invertase-mutarotase-glucose oxidase was investigated and optimized for determination of toxic substances. Working conditions for all enzymes were optimized, basic analytical characteristics of the developed multibiosensor were considered with regards to its prospective application in inhibitory analysis of toxins in aqueous solutions of the environmental samples.

This work was supported by National Academy of Sciences of Ukraine in the frame of Scientific and Technical Programme "Sensor systems for medical-ecological and industrial-technological problems".

О. О. Солдаткін, О. С. Павлюченко, О. Л. Кукла, В. М. Архипова, С. В. Дзядевич, О. П. Солдаткін, Г. В. Сльська

Оптимізація роботи мультибіосенсора при інгібіторному аналізі токсинів

Резюме

Досліджено роботу високочутливого та селективного мультибіосенсора на основі низки іммобілізованих ферментів як біоселективних елементів та матриці рН-чутливих польових транзисторів як перетворювачів біохімічного сигналу в електричний. Для створення біоселективних елементів мультибіосенсора використано ферменти ацетилхолінестеразу, бутирилхолінестеразу, уреазу, глюкозооксидазу та триферментну систему інвертаза-мутаротаза-глюкозооксидаза, які демонструють високу чутливість до дії токсинів. Визначено оптимальні концентрації субстратів, використані при інгібіторному аналізі, вони становлять для ацетилхоліну 10 мM, бутирилхоліну - 5 мМ, сечовини - 5 мM, иукрози - 5 мМ та глюкози - 2 мМ. Час інкубачї мультибіосенсора в токсичних 


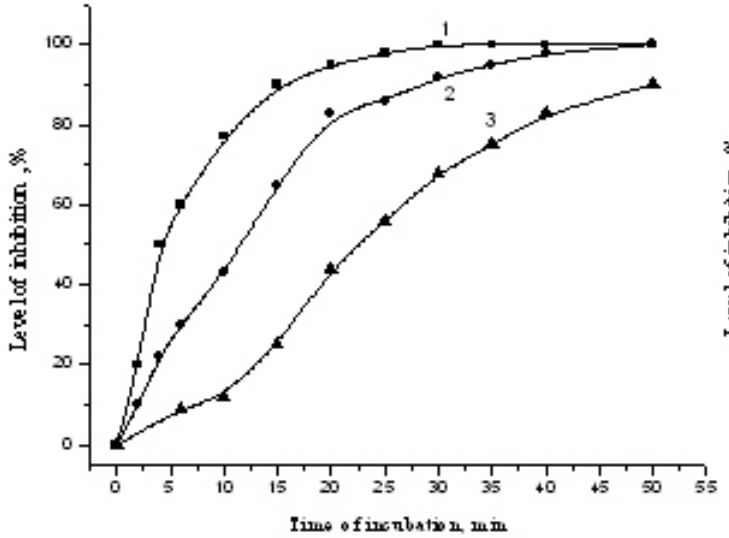

A

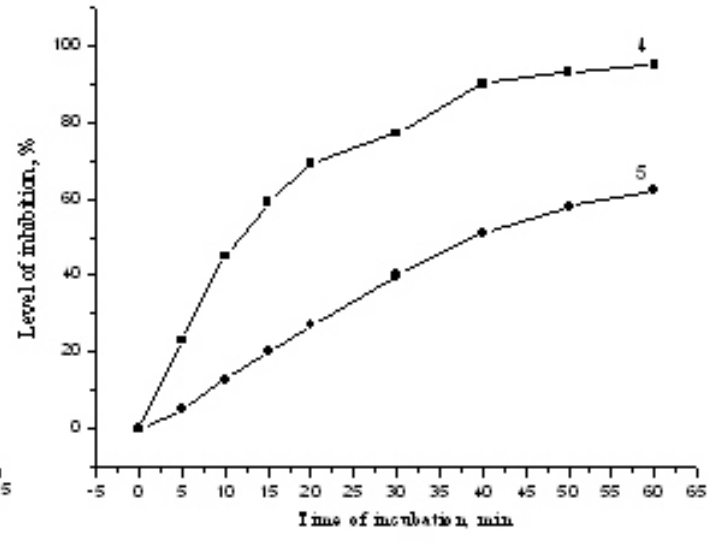

$\mathrm{B}$

Fig. 7. Dependence of inhibition of enzymatic systems on time of multibiosensor incubation in $25 \mu \mathrm{M} \mathrm{Hg}{ }^{2+}$ (A) and $50 \mu \mathrm{M}$ trichlorphone (B) (1-three-enzyme system, $2-G O D, 3$ - urease, $4-A C h E, 5-B u C h E)$. Measurement in 2 mM phosphate buffer, pH 6.5. Substrate concentration: $10 \mathrm{mM} \mathrm{ACh,} 5 \mathrm{mM} \mathrm{BuCh,} 5 \mathrm{mM}$ urea, $5 \mathrm{mM}$ sucrose, and $2 \mathrm{mM}$ glucose.

розчинах дорівнює 20 хв. Показано, щео перехресного впливу субстратів для всіх використаних ферментних систем майже немає. Перевірено також інгібіторну дію окремих токсинів та їхніх сумішей на біоселективні елементи мультибіосенсора.

Ключові слова: мультибіосенсор, іммобілізовані ферменти, рН-чутливі польові транзистори, інгібіторний аналіз, токси$\mathrm{Hu}$.

А. А. Солдаткин, А. С. Павлюченко, А. Л. Кукла, В. Н. Архипова, С. В. Дзядевич, А. П. Солдаткин, А. В. Ельская

Оптимизация работы мультибиосенсора при ингибиторном анализе токсинов

Резюме

Исследована работа высокочувствительного и селективного мультибиосенсора на основе ряда иммобилизованных ферментов как биоселективных элементов и матрицы рН-чувствительных полевых транзисторов как преобразователей биохимического сигнала в электрический. Для создания биоселективных элементов мультибиосенсора использовали ферменты ацетилхолинэстеразу, бутирилхолинэстеразу, уреазу, глюкозооксидазу и трехферментную систему инвертаза-мутаротаза-глюкозооксидаза, демонстрирующие высокую чувствительность $к$ действию токсинов. Определены оптимальные кониентрации субстратов для использования в ингибиторном анализе, которые составили для ацетилхолина 10 мМ, бутирилхолина - 5 мМ, мочевины - 5 мM, сахарозы - 5 мМ и глюкозы - 2 мМ. Время инкубации мульти-биосенсора в токсичных растворах составило 20 мин. Показано, что перекрестное влияние субстратов для всех использованных ферментных систем практически отсутствует. Также проверено действие отдельных токсинов и их смесей на биоселективные элементы мультибиосеносра.
Ключевые слова: мультибиосенсор, иммобилизованные ферменты, рН-чувствительные полевые транзисторы, ингибиторный анализ, токсины.

\section{REFERENCES}

1. Солдаткін О. О., Сосовська О. Ф., Бенілова І. В., Гончар M. В., Корпан Я. I. Ензимний кондуктометричних сенсор для визначення формальдегіду у модельних розчинах // Біополімери і клітина.-2005.-21, № 5.-С. 425-432.

2. Сосовська О. Ф., Павлішко Г. М., Парижак С. Я., Гончар M. В., Корпан Я. I. Формальдегідний кондуктометричний біосенсор на основі рекомбінованої формальдегіддегідрогенази дріжджів Hansenula polymorpha // Біополімери і клітина.-2008.-24, № 2.-С. 135-141.

3. Dzyadevych S. V., Mai Anh T., Soldatkin A. P., Duc Chien N., Jaffrezic-Renault N., Chovelon J.-M. Development of enzyme biosensor based on $\mathrm{pH}$-sensitive field-effect transistors for detection of phenolic compounds // Bioelectrochemistry.-2002.-55.-P. 79-81.

4. Korpan Y. I., Gonchar M. V., Sibirny A. A.., Martelet C., El'skaya A. V., Gibson T. D., Soldatkin A. P. Development of highly selective and stable potentiometric sensors for formaldehyde determination // Biosensors and Bioelectronics.-2000.-15.-P. 77-83.

5. Berezhetskyy A. L., Durrieu C., Nguyen-Ngoc H., Chovelon J.-M., Dzyadevych S. V., Tran-Minh C. Conductometric biosensor based on whole-cell microalgae for assessment of heavy metals in wasterwater // Біополімери і клітина.2007.-23, № 6.-C. 511-518.

6. Soldatkin A. P., Arkhypova V. N., Dzyadevych S. V., El'skaya A. V., Gravoueille J-M., Jaffrezic-Renault N., Martelet C. Analysis of the potato glycoalkaloids by using of enzyme biosensor based on pH-ISFETs // Talanta.-2005.-66.-P. 2833.

7. Dzyadevych S. V., Soldatkin A. P., Arkhypova V. N., El'skaya A. V., Chovelon J-M.,. Georgiou C. A., Martelet C., 
Jaffrezic-Renault $N$. Early-warning electrochemical biosensor system for environmental monitoring based on enzyme inhibition // Sensors and Actuators B.-2005.-105.P. 81-87.

8. Arkhypova V. N., Dzyadevych S. V., Soldatkin A. P., El'skaya A. V., Martelet C., Jaffrezic-Renault N. Development and optimisation of biosensors based on $\mathrm{pH}$-sensitive field effect transistors and cholinesterases for sensitive detection of solanaceous glycoalkaloids // Biosensors and Bioelectronics.-2003.-18.-P. 1047-1053.

9. Солдаткін О. О., Пєшкова В. М., Дзядевич С. В., Солдаткін О. П., Сльська Г. В. Кондуктометричний біосенсор на основі триферментної системи для селективного визначення іонів важких металів // Sensor Electronics and Microsystem Technologies.-2008.-2.-C. 48-57.

10. Arkhipova V. N., Dzyadevych S. V., Soldatkin A. P., El'skaya A. V., Jaffrezic-Renault $N$., Jaffresic $H$., Martlet $C$. Multibiosensor based on enzyme inhibition analysis for determination of different toxic substances // Talanta.-2001.55.-P. 919-927.

11. Kukla A. L., Kanjuk N. I., Starodub N. F., Shirshov Yu. M. Multienzyme electrochemical sensor array for determination of heavy metal ions // Sensors and Actuators B.-1999.57.-P. 213-218.
12. Moreno L., Merlos A., Abramova N., Jimenez C., Bratov A. Multi-sensor array used as an «electronic tongue» for mineral water analysis // Sensors and Actuators B.-2006.-116.P. 130-134.

13. Touloupakisa E., Giannoudi L., Piletsky S. A., Guzzella L., Pozzoni F., Giardi M. T. A multi-biosensor based on immobilized Photosystem II on screen-printed electrodes for the detection of herbicides in river water // Biosensors and Bioelectronics.-2005.-20.-P. 1984-1992.

14. Солдаткін О. О., Назаренко О. А., Павлюченко О. С., Кукла О. Л., Архипова В. М., Дзядевич С. В., Солдаткін О. П., Єльська Г. В. Оптимізація роботи ферментних біоселективних елементів як складових потенціометричного мультибіосенсора // Біополімери і клітина.-2008.-24, № 1.-C. $42-50$.

15. Дзядевич С. В. Биосенсоры на основе ионселективных полевых транзисторов: теория, технология, практика // Біополімери і клітина.-2004.-20, № 1-2.-С. 7-16.

UDC 577.151.4:544.475:543.554.2 Received 13.05.08 